\title{
Lower Triassic bryozoan beds from Ellesmere Island, High Arctic, Canada
}

\author{
Aymon Baud ${ }^{1}$, Hans Arne Nakrem², Benoit Beauchamp ${ }^{3,4}$, Tyler W. Beatty ${ }^{4}$, Ashton F. Embry ${ }^{5}$ \& \\ Charles M. Henderson ${ }^{4}$ \\ 1 Geological Museum, Lausanne University, Quartier UNIL-Dorigny, Bâtiment Anthropole, CH-1015 Lausanne, Switzerland \\ 2 Natural History Museum, University of Oslo, PO Box 1172 Blindern, NO-0318 Oslo, Norway \\ 3 Department of Geoscience, University of Calgary, 2500 University Drive N.W., Calgary, Alberta, T2N 1N4 Canada \\ 4 Department of Geology and Geophysics, University of Calgary, 2500 University Drive N.W., Calgary, Alberta, T2N 1N4 Canada \\ 5 Geological Survey of Canada, 3303 33rd St. NW, Calgary, Alberta, T2L 2A7 Canada
}

Keywords

Arctic; Arcticopora; bryozoans; Canada; Spitsbergen; Triassic.

\section{Correspondence}

Hans Arne Nakrem, Natural History Museum, University of Oslo, PO Box 1172 Blindern, NO-0318 Oslo, Norway.

E-mail: h.a.nakrem@nhm.uio.no

doi:10.1111/j.1751-8369.2008.00071.x

\begin{abstract}
In the Sverdrup Basin (Canadian Arctic), the Lower Triassic Blind Fiord Formation, comprising siltstone and shale, overlies various Middle to Late Permian (post-Wordian) sedimentary units. This formation is subdivided into three members: the Confederation Point, Smith Creek and Svartfjeld members of, respectively, Griesbachian-Dienerian, Smithian-Spathian and Spathian ages. Lower Triassic bryozoan beds are known from many sections of Ellesmere Island, but have never been studied in detail. During the Early Triassic biotic recovery interval, immediately following the Permian/Triassic extinction event, only one new bryozoan genus evolved in the Boreal region: Arcticopora. The first lower Triassic bryozoan bed appears in the upper part of the Confederation Point Member, and is dated as late Dienerian. Succeeding bryozoan levels occur in the upper Smith Creek Member, and are late Smithian-early Spathian in age. Bryozoan beds occupy a similar stratigraphic position in Spitsbergen. There, they occur scattered in silt to coarse sandstone beds, but also in bryozoan-dominated packstone beds resembling the packstone units in the uppermost part of the Confederation Point Member of Ellesmere Island. Previously, bryozoan-rich beds of Triassic age have not been reported, and the present work fills an important time gap in the bryozoan carbonate database.
\end{abstract}

In the Sverdrup Basin of the Canadian Arctic Archipelago, a sponge-dominated skeletal siliceous factory, active during the Middle-Late Permian, produced (up until the mass-extinction event at the end of the Permian) a succession of chert-dominated units, best represented by the Van Hauen and Lindström formations (Gates et al. 2004). As a consequence of climate change and the initiation of voluminous, fine terrigenous input, beginning in the upper part of the late Permian Van Hauen and Lindström formations, the highly productive spiculite factory disappeared completely (Beauchamp et al. 1999). The declining skeletal carbonate factory, represented by the cherty limestone of the Degerböls Formation, ceased to exist following the end of the Guadalupian extinction (Beauchamp \& Baud 2002), giving way to very sporadic ammonoid and bivalve pro- duction, whereas the non-skeletal carbonate factory rarely produced concretion levels.

The basal Blind Fiord Formation, representing a regional transgression in the late Changhsingian, overlies various Permian sedimentary units, and is diachronous, as it first onlapped depressions between structural highs.

Bryozoans of the orders Trepostomata, Cystoporata, Cryptostomata and Fenestrata were widespread and diverse in the Permian of both Boreal and Tethyan seas (Ross \& Ross 1990; Ross 1995; Gilmour \& Morozova 1999). Few publications exist on such faunas from the Permian of the Sverdrup Basin (Morozova \& Kručinina 1986; Sakagami 1998; Ernst \& Nakrem 2005, 2007; Reid et al. 2007), but bryozoans are mentioned as a common fossil group in several general descriptions of the geology of this area. Only a few Paleozoic genera survived the 


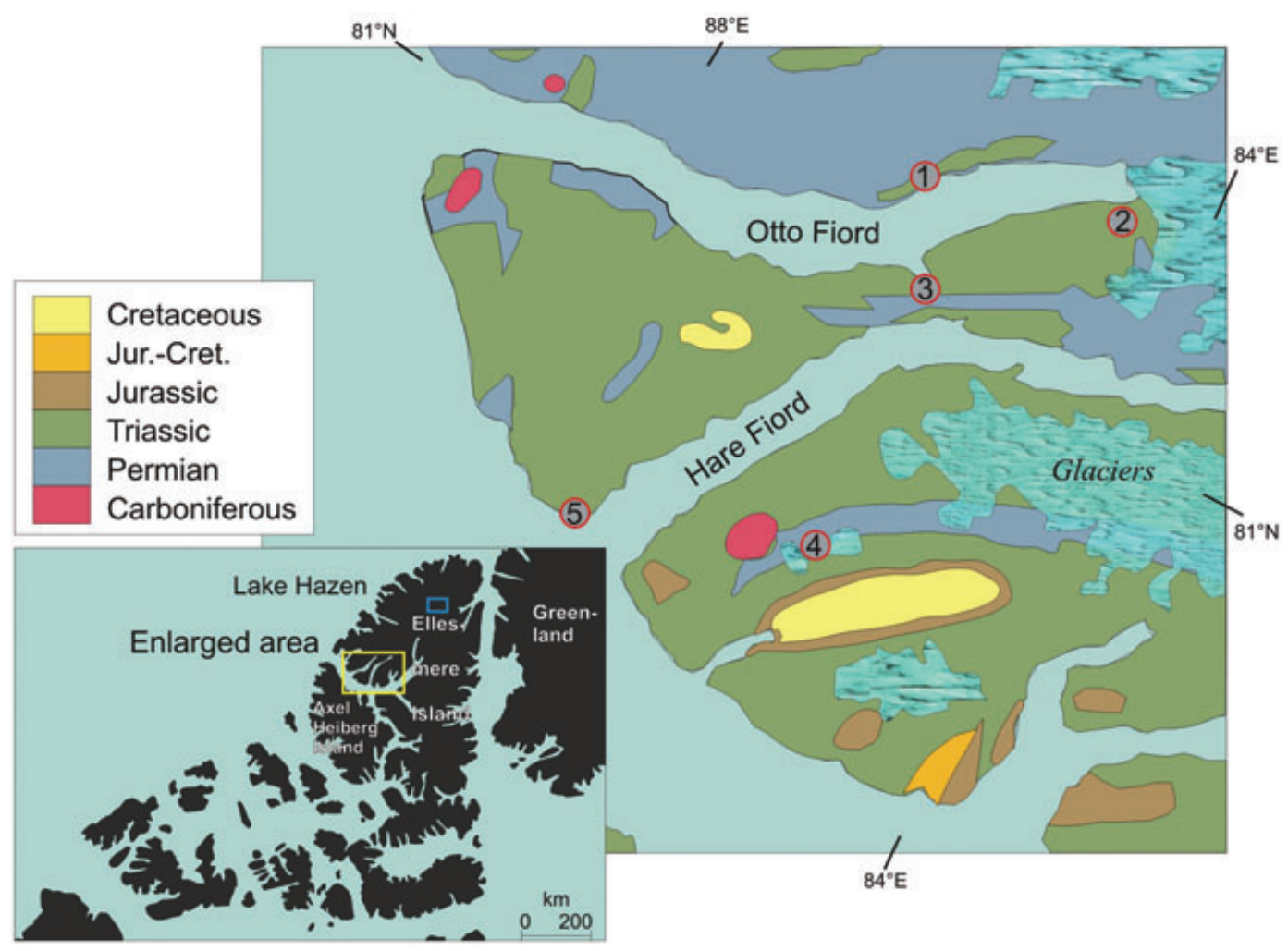

Fig. 1 Location map of the Otto Fiord-Hare Fiord area (indicated by the yellow rectangle on the inset map), Lake Hazen (indicated by the blue rectangle on the inset map) and simplified geological map of the north-west part of Ellesmere Island with bryozoan localities indicated: 1, northern shore of Otto Fiord; 2, south of the head of Otto Fiord; 3, Van Hauen Pass; 4, Blue Mountains; and 5, Confederation Point.

Permian/Triassic boundary, and only two new genera are known to make their first appearance during the Early Triassic: Arcticopora, originally described from Ellesmere Island (Fritz 1961), and Dyscritellopsis, originally described from New Zealand (Schäfer \& Grant-Mackie 1994). Until now, only six undisputed Early Triassic bryozoan species have formally been described, all from the Boreal region. This is in strong contrast to the increased diversity through the Middle and Late Triassic, with a total of more than 40 species (see reviews in Schäfer $\&$ Grant-Mackie 1994; Schäfer et al. 2003), and the biotic recovery of bryozoans clearly lasted longer than the initial five million years of the Triassic. A taxonomic review of Arcticopora (Nakrem \& Ernst unpubl. ms.) includes taxa that are assigned to Arcticopora from other Triassic localities, and this genus is therein considered to have a complete Triassic stratigraphic range (see also Astrova 1978; Morozova 1986). All of the mentioned orders became extinct by the end of the Triassic.

Lower Triassic bryozoan beds are known from many sections on Ellesmere Island (Figs. 1-5), but have not previously been studied in detail (Baud \& Beauchamp 2006). New Lower Triassic bryozoan beds were found in two sections of the Otto Fiord area during the 1992 geological expeditions to Ellesmere Island. A survey of the two sections was completed in 1994 by AFE, AB and CMH. A new section at Confederation Point was collected in 2004 by TWB and CMH. Lithological sections from these localities are presented in Figs. 2-5.

\section{Material}

During the present study the type material of Arcticopora was re-studied, and new material from several localities in Ellesmere Island was thin-sectioned and investigated. Material from the following localities (all from the Blind Fiord Formation; Fig. 1) was studied.

- Blue Mountains $\left(80^{\circ} 47^{\prime} \mathrm{N}, 85^{\circ} 02^{\prime} \mathrm{W}\right)$, Smith Creek Member (Embry collection 1992), Smithian age.

- Northern shore of Otto Fiord $\left(81^{\circ} 11^{\prime} \mathrm{N}, 86^{\circ} 11^{\prime} \mathrm{W}\right), 10 \mathrm{~m}$ below the top of the Confederation Point Member (Beauchamp/Baud collection), Late Dienerian age (Fig. 3).

- South of the head of Otto Fiord $\left(80^{\circ} 15^{\prime} \mathrm{N}, 84^{\circ} 37^{\prime} \mathrm{W}\right)$, upper part of the Smith Creek Member (Beauchamp/ Baud collection), Late? Smithian age (Fig. 4). 


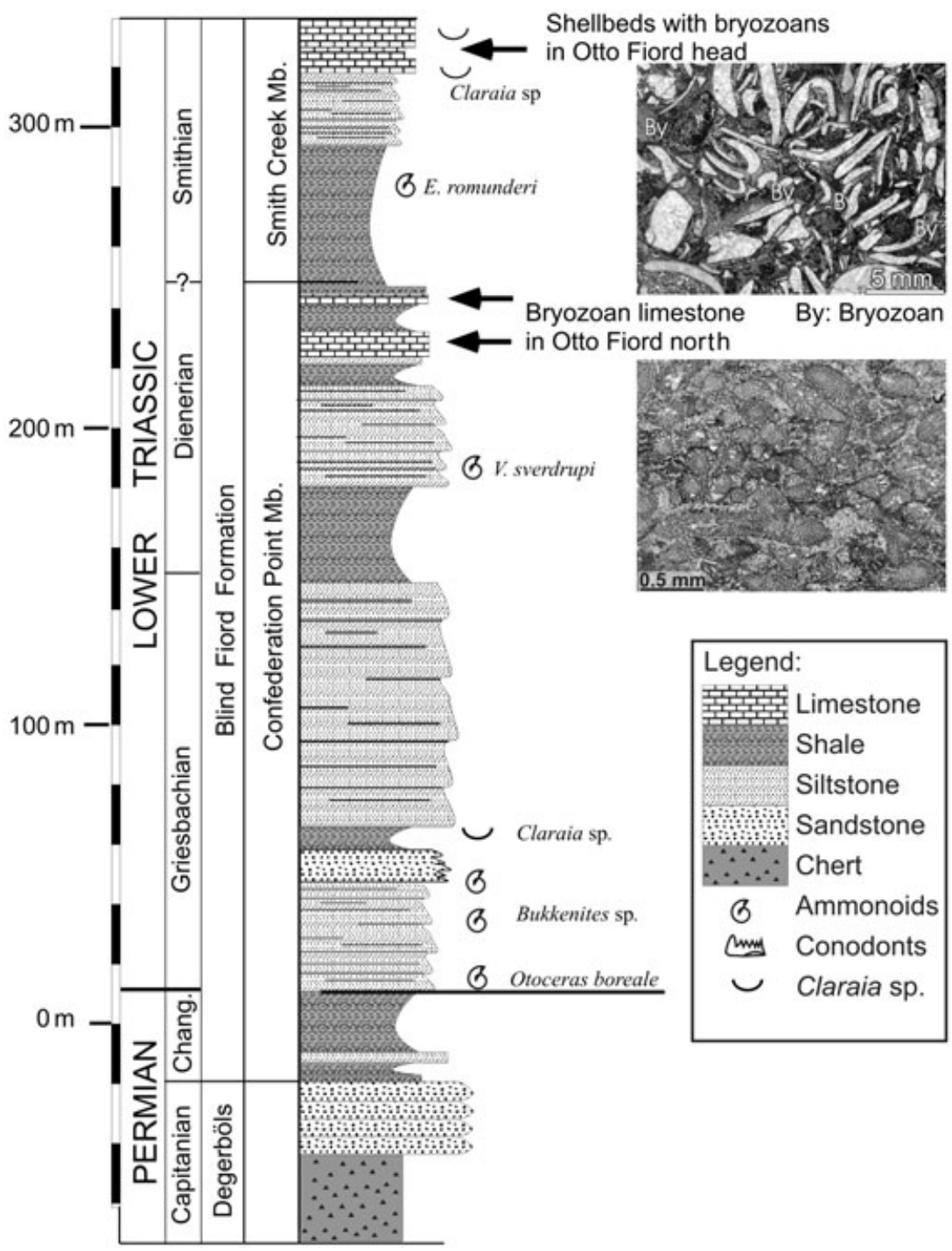

Fig. 2 Stratigraphic position of the bryozoan beds in Otto Fiord area, and microfacies of the lower and upper bryozoan beds. Chang., Changhsingian.
- Confederation Point $\left(80^{\circ} 37^{\prime} \mathrm{N}, 87^{\circ} 31^{\prime} \mathrm{W}\right)$, upper part of the Conferederation Point Member (Beatty collection), Late Dienerian age (Fig. 5).

- Northern shore of Lake Hazen (published in Fritz 1961), ?Dienerian-Smithian age.

- North-east side of Van Hauen Pass, $450 \mathrm{~m}$ above base of Blind Fiord Fm (published in Bolton 1961), ?Dienerian-Smithian age.

The correlation of Lower Triassic units of Ellesmere Island, central East Greenland and Spitsbergen with bryozoan occurrences is shown in Fig. 6. All of the illustrated thin sections (Figs. 7-9) are housed in the collection of type and illustrated palaeontological material of the Natural History Museum, University of Oslo.

\section{Geological framework}

As a result of a major sea-level lowstand, the Sverdrup Basin may have been nearly landlocked during the Late Permian: a basinwide unconformity has been interpreted to separate the Permian and Triassic rocks (Thorsteinsson 1974). The base of the Triassic has traditionally been correlated with the base of the Confederation Point Member shale of the Blind Fiord Formation. However, an uppermost Permian unit comprising shale and spiculitic chert has recently been interpreted as a transgressive systems tract of an uppermost Permian-Lower Triassic sequence (Gates et al. 2004), which thereby restricted the major unconformity to the margins of the Sverdrup Basin only. This sequence is the first of nine regional third- 
Fig. 3 Stratigraphy and views of the lower bryozoan beds at Otto Fiord Camp W. 1, Upper surface of a bryozoan limestone bed. 2, Aerial view of the small creek $4 \mathrm{~km}$ west of Otto Fiord Camp. CP, Confederation Point Member; DG, Degerböls Formation; SC, Smith Creek Member; Sv, Svartfjeld Member. Shading defined by key in Fig. 2.

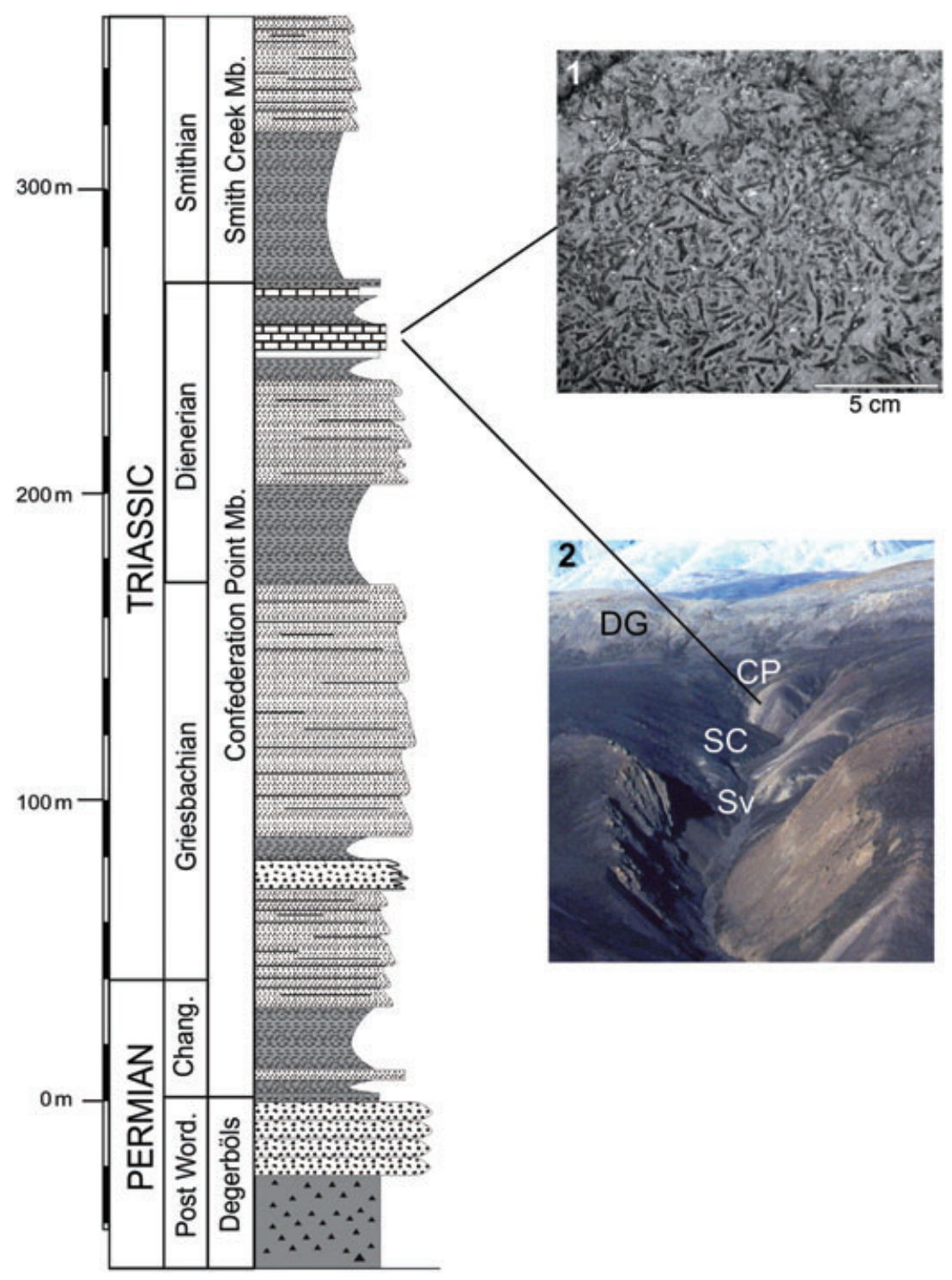

order transgressive-regressive sequences recognized in the latest Permian to Triassic succession of the Sverdrup Basin (Embry 1988), and is dated as Late Changhsingian to Late Griesbachian (Henderson \& Baud 1997).

The Blind Fiord Formation comprises three broad unconformity-bounded sequences (Embry 1991, 1997). The basal sequence, which roughly coincides with the Confederation Point Member of the formation, ranges in thickness from a few hundreds of metres to more than $1 \mathrm{~km}$. It comprises fine-grained clastic sediments of variably deep-water basinal, slope or outer shelf origin, passing upwards and landwards into increasingly shallow-water siltstones, sandstones and conglomerates, deposited in various environments ranging from shallow subtidal to fluvial. The member is dated as late Changhsingian to late Induan (late Dienerian). The Smith Creek Member coincides with the next sequence, and ranges in thickness from 100 to $300 \mathrm{~m}$, with the same type of clastic sediments from deep-water basinal shales to landward sandstones and conglomerates. The age is from late Induan to middle Olenekian (early Spathian). The upper sequence is the Svartfjeld Member (late Olenekian), which is up to $400 \mathrm{~m}$ thick. It is interesting to note that the bryozoan beds with limestones appear in the regressive, upper part of the basal and subsequent unconformity-bounded sequences, at the top of the Confederation Point and Smith Creek members (Fig. 2). 


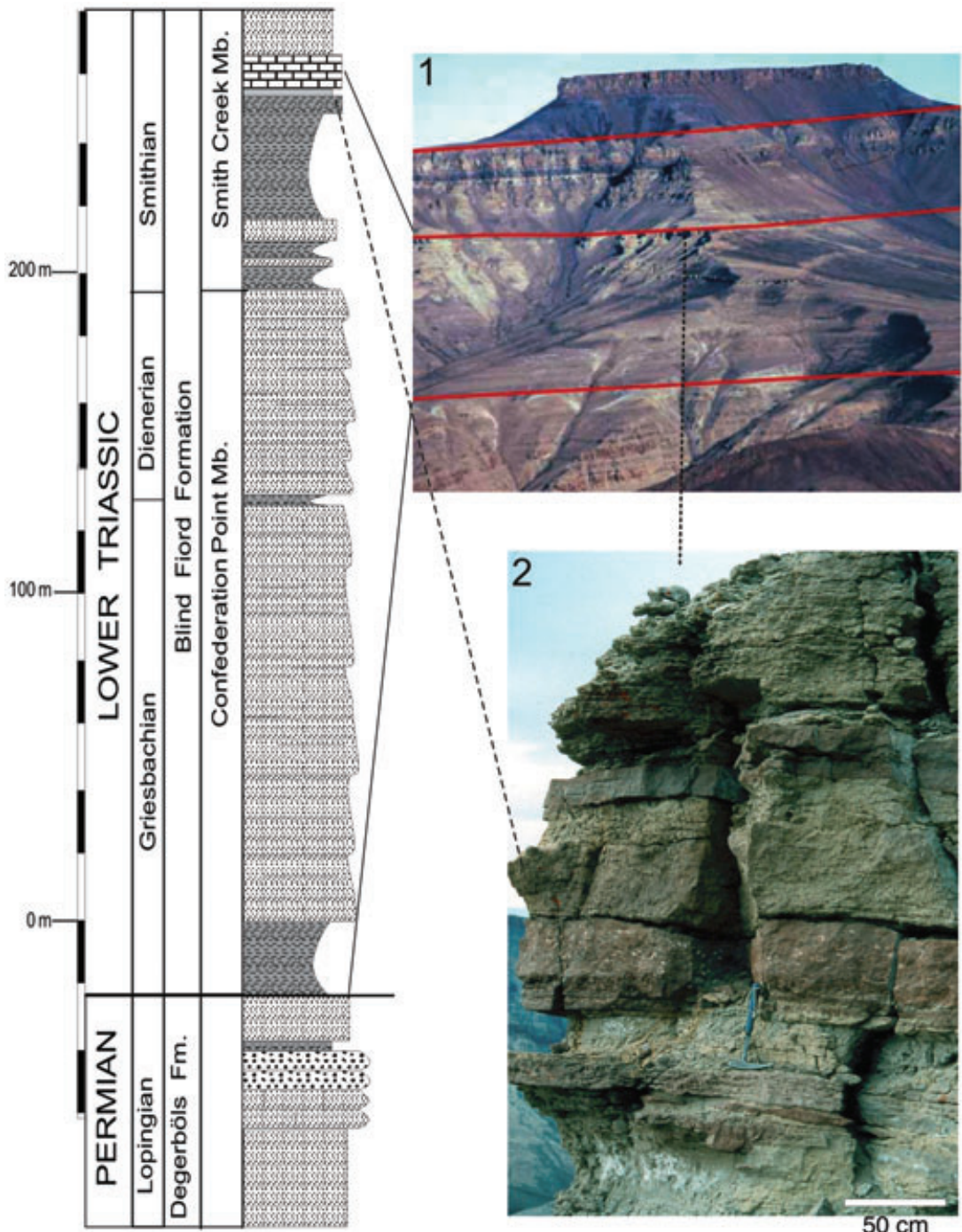

Fig. 4 Stratigraphy and views of the upper bryozoan beds at the head of Otto Fiord. 1, View of the Otto Fiord head section with the main unconformity-bounded sequences (red lines). 2, Shell beds (tempestites) at the top of the Smith Creek Member. Shading defined by key in Fig. 2.

\section{Bryozoan beds in the Otto Fiord area}

The lower bryozoan beds occur along a small creek (Figs. 1, 3) on the northern shore of Otto Fiord, $5 \mathrm{~km}$ west of a large delta where the base camp was established. In this area, the Blind Fiord Formation is about $600 \mathrm{~m}$ thick, and the Confederation Point Member is about $250 \mathrm{~m}$ thick. The Confederation Point Member lithologies consist mainly of dark-grey shales (mudstones) at the base, and of light-grey to brown siltstones higher up. The first sandstone level appears at $120 \mathrm{~m}$ above the base, and rare sandstone beds are intercalated higher in the siltstone succession. At $220 \mathrm{~m}$ above the base a limy sandstone bed is rich in bivalve shells, and contains the first bryozoans. Between 230 and $240 \mathrm{~m}$ above the base there are about 10 bryozoan carbonate packstone beds (a bedding surface is illustrated in Fig. 3) within the siltshale succession. They are overlain by $10 \mathrm{~m}$ of coarse siltstone/sandstone that mark the top of the Confederation Point Member. Above, the Smith Creek Member is $100 \mathrm{~m}$ thick, and comprises transgressive shale, followed by regressive siltstone and sandstone containing a Euflemingites fauna of middle Smithian age.

Samples from this lower bryozoan bed provided the following conodonts: Neospathodus dieneri, Neospathodus cristigalli, Ellisonia triassica and fragments of gondolellids that resemble Borinella sp. These forms indicate a Late Dienerian age, and correspond to those found associated with the bryozoan beds at the Confederation Point locality.

The upper bryozoan beds occur on the flank of a large valley, south of the head of Otto Fiord (Figs. 1, 4). Here, the Confederation Point Member is $220 \mathrm{~m}$ thick (Fig. 4). The bryozoans were found within coquinal shell beds in the upper part of the Smith Creek Member, which is $95 \mathrm{~m}$ thick. Overlying the transgressive shales with con- 
Fig. 5 Stratigraphy and position of the lower bryozoan beds at the Confederation Point section. Ch., Changhsingian; G., Griesbachian. Shading defined by key in Fig. 2 .

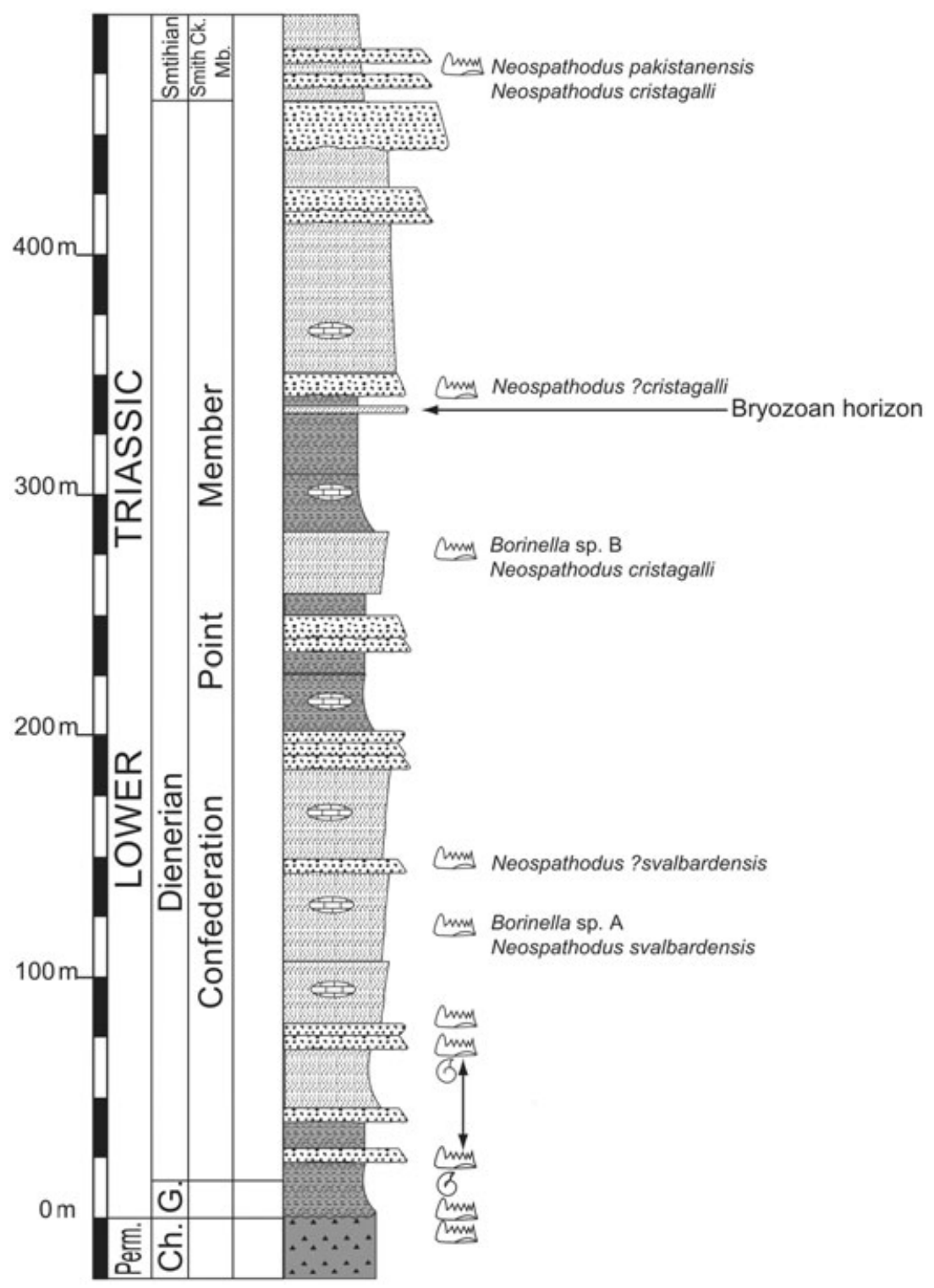

cretions and a highstand siltstone unit, the regressive upper 20-m unit, which is cliff forming, consists of carbonate tempestite beds (Fig. 4) containing bivalves, smooth brachiopods, crinoids and bryozoans (Fig. 9g, h).

\section{Bryozoan beds in the Confederation Point area}

In the Confederation Point area, Svartfjeld Peninsula, north-western Ellesmere Island (Figs. 1, 5), the Lower Triassic bryozoan beds occur in an east-facing cliff exposure, in a steep gully formed by an unnamed creek. The creek is situated $2 \mathrm{~km}$ north of Smith Creek, and is the location of the stratotype sections of the Confederation Point and the Smith Creek members of the Blind Fiord Formation (Embry 1986). At the unnamed creek, the
Confederation Point Member of the Blind Fiord Formation is $475 \mathrm{~m}$ thick (Embry 1986); a composite thickness of $1062 \mathrm{~m}$ has been reported for the entire Blind Fiord Formation in this area (Ogg \& Steiner 1991). The Confederation Point Member at its base comprises dark-grey shale and grey silty shale, with common siltstone and rare fine-grained sandstone interbeds. The sandstone beds commonly contain casts of feeding and locomotary burrows along their soles. Concretionary levels are common throughout much of the section.

The bryozoans occur $333 \mathrm{~m}$ above the base of the Confederation Point Member, in a 30 -cm-thick limy fine-grained sandstone bed, and again $1 \mathrm{~m}$ higher in a 20-cm-thick limy fine-grained sandstone bed (Fig. 5). Disarticulated, abraded and variably oriented bivalve shells 
are common in these beds. The bryozoan-bearing beds are overlain by thin-bedded siltstone, interbedded siltstone and fine sandstone that become progressively thicker bedded and coarser grained near the top of the Confederation Point Member (Fig. 5). The base of the Smith Creek Member is marked by a transgressive surface with siltstone over sandstone. Thick, convolute bedded sandstone beds are common in the basal $20 \mathrm{~m}$ of the Smith Creek Member, but become rarer higher up. The Euflemingites romunderi limestone marker horizon occurs here at $60 \mathrm{~m}$ above the base of the Smith Creek Member. This limestone is a condensed horizon that is likely to correspond to the maximum flooding surface of a third-order sequence (Embry 1986).

The age of the bryozoan-bearing beds is Late Dienerian, based on available conodont data for the section at the unnamed creek north of Smith Creek (Beatty et al. 2006; Beatty et al. unpubl. ms.). The bryozoan beds themselves were sampled for conodonts, but recovery was limited to fragments of Neospathodus ?cristagalli. Samples bracketing the bryozoan horizon, however, provide good constraints on the age of the bryozoans (Fig. 5).

\section{Other Ellesmere Island bryozoan localities}

Early Triassic bryozoans have previously been reported from Lake Hazen by Fritz (1961). Bolton (1961) described bryozoans from the north-east side of Van Hauen Pass, $450 \mathrm{~m}$ above the base of Blind Fiord Formation (Dienerian-Smithian age). Moore (1981) shows bryozoans in shell beds and limestones on illustrated Blind Fiord profiles from the Krieger Mountains, and from the Hare Fiord Head.

\section{Other Triassic Boreal bryozoan occurrences}

According to Nakrem \& Mørk (1991), bryozoan beds occupy a similar stratigraphic position in the DienerianSmithian Vardebukta and Tvillingodden formations of Spitsbergen. There, they occur scattered in silt to coarse sandstone beds, but also in bryozoan-dominated packstone units (Myalina beds) resembling the packstone units in the uppermost part of the Confederation Point Member of Ellesmere Island.

All Early Triassic trepostome bryozoans were restricted to, or dominant in, well-bedded, alternating siliciclasticcarbonate sequences of non-tropical shelves outside the Tethys. These basins (Arctic Canada, Svalbard, central East Greenland and Siberia) were positioned at high latitudes. Today, as is well seen in the fossil record, temperate and subpolar open shelf conditions are favourable for bivalves, bryozoans and brachiopods, which may dominate bottomlevel suspension-feeding communities (Nelson 1988). One previously noted exception is the Triassic, for which

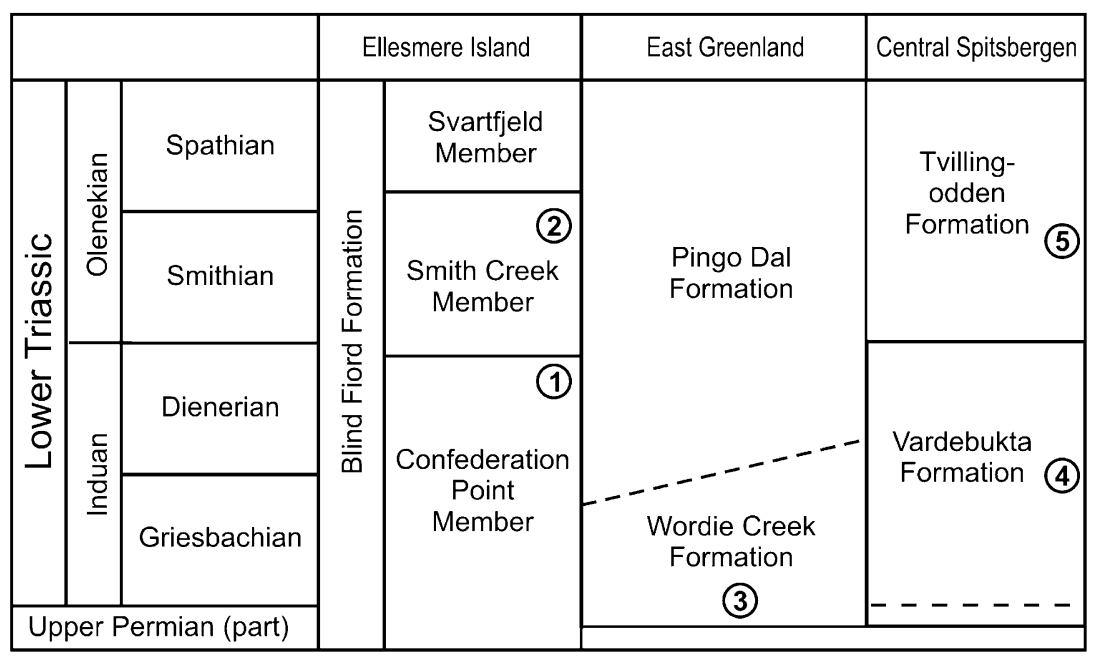

Fig. 6 Correlation of Lower Triassic lithostratigraphic units of Ellesmere Island (Embry 1991), central East Greenland (Perch-Nielsen et al. 1974; Bjerager et al. 2006) and Spitsbergen (Mørk et al. 1999; Wignall et al. 1998). 1, 2, Lower and upper bryozoan beds of Ellesmere Island. 3, Bryozoans in the lowermost Triassic strata of central East Greenland. 4, 5, Lower and upper bryozoan beds of central Spitsbergen (Nakrem \& Mørk 1991). Dashed lines indicate uncertain correlations.

Fig. 7 (a-c) Reworked(?) bryozoans in the lowermost Triassic beds of Greenland (collection: P. Wignall). (d-h) Uppermost Permian bryozoans from Ellesmere Island, $1.1 \mathrm{~m}$ below the top of the Degerböls Formation, Otto Glacier (collection: A. Baud \& B. Beauchamp). (a) Tabulipora sp., tangential section; Jameson Land, Greenland, Lowermost Triassic (collection of type and illustrated palaeontological material of the Natural History Museum, University of Oslo, PMO 207.888a). (b) Tabulipora sp., transverse section; Jameson Land, Greenland, lowermost Triassic (PMO 207.888b). (c) Tabulipora sp., Iongitudinal section; Jameson Land, Greenland, lowermost Triassic (PMO 207.888c). (d) Transverse section of Ramipora sp. and tangential section of Rectifenestella sp. (PMO 170.790). (e) Transverse section of Timanodictya sp. (PMO 170.790). (f) Tangential section of Dyscritella sp. (PMO 170.790). (g) Permoheloclema sp., transverse and longitudinal section (PMO 170.790). (h) Transverse to longitudinal section of Ramipora sp. (PMO 170.790.) 

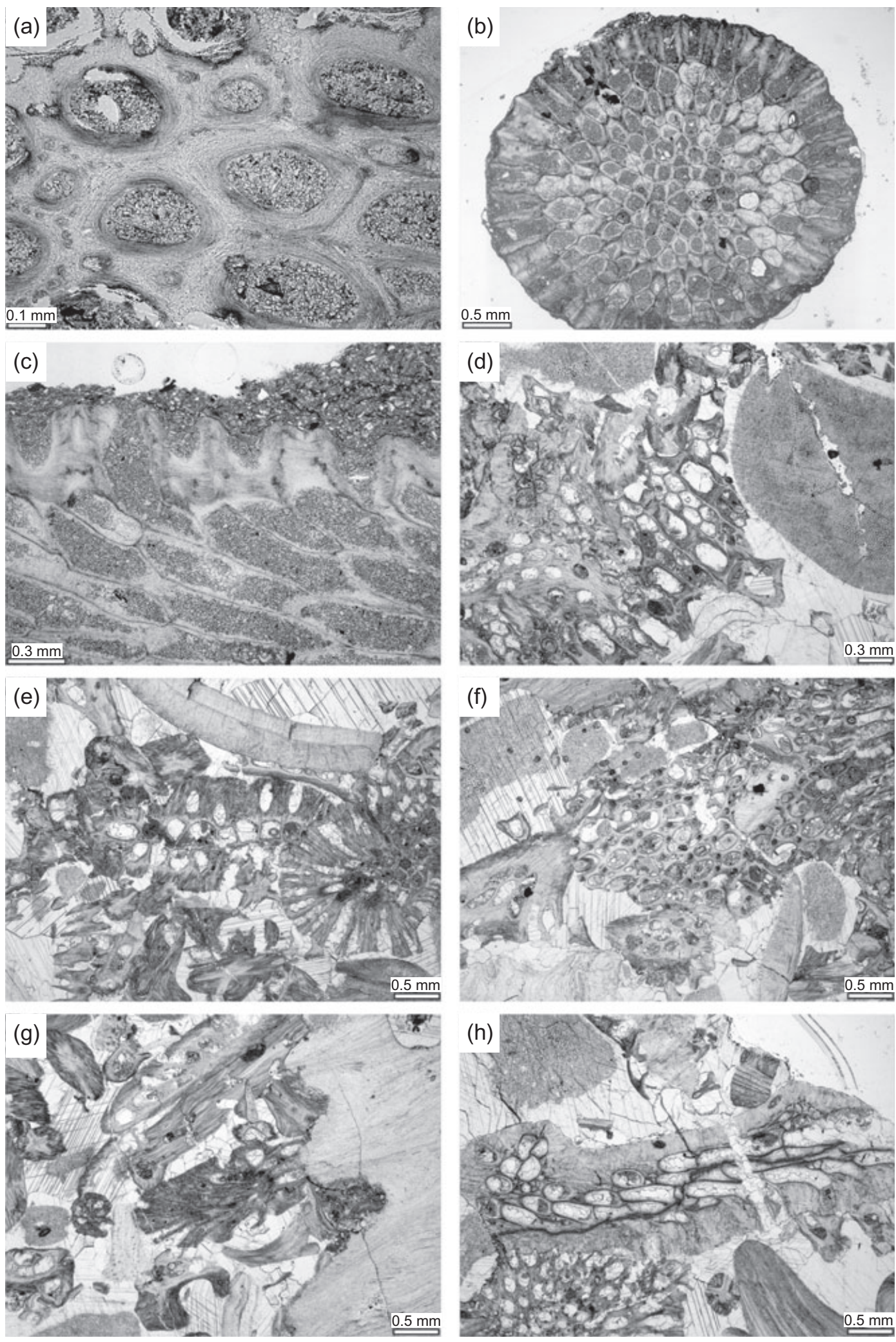

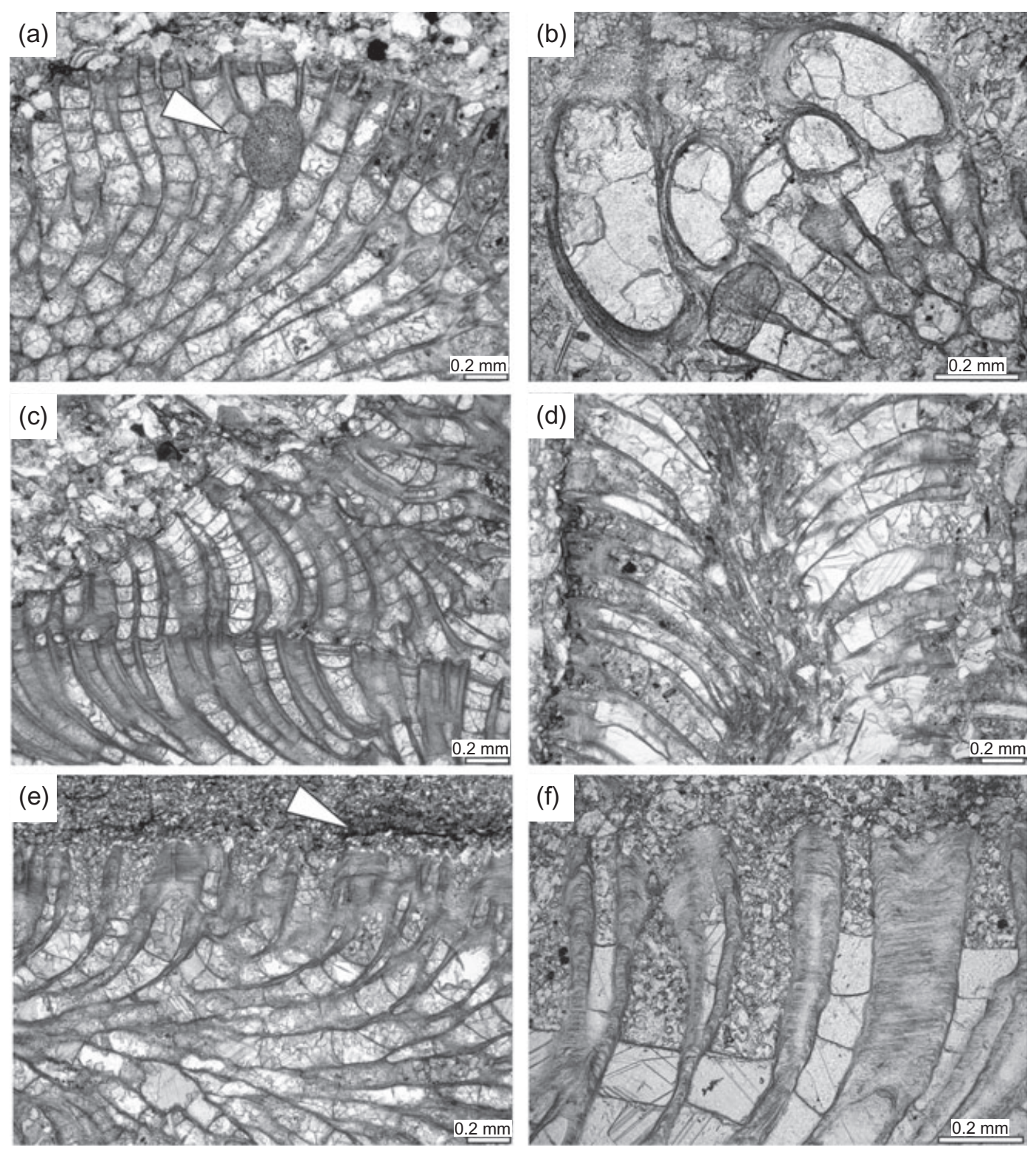

Fig. 8 (a) Arcticopora sp. with enclosed crinoid fragment (arrow); south of the head of Otto Fiord, upper part of the Smith Creek Member, Smithian (palaeontological collection of the Natural History Museum, University of Oslo, PMO 170.787; collected by A. Baud \& B. Beauchamp). (b) Arcticopora sp. with attached microconchid tubeworm or foraminiferan; Blue Mountains, Smith Creek Member, Smithian (PMO 138.109; collected by A. Embry). (c) Arcticopora sp. showing self-overgrowth; northern shore of Otto Fiord, $10 \mathrm{~m}$ below top of the Confederation Point Member, late Dienerian (PMO 170.796; collected by A. Baud \& B. Beauchamp.) (d) Arcticopora sp. Iongitudinal section, endozone crushed; northern shore of Otto Fiord, $10 \mathrm{~m}$ below top of the Confederation Point Member, late Dienerian (PMO 170.792; collected by A. Baud \& B. Beauchamp). (e) Arcticopora sp. re-deposited clast, arrow points at transition between clast and surrounding sediment; Confederation Point, Confederation Point Member, late Dienerian (PMO 170.800; collected by T. Beatty). (f) Arcticopora sp. longitudinal section; northern shore of Otto Fiord, near top of the Confederation Point Member, late Dienerian (PMO 207.890; collected by A. Baud \& B. Beauchamp).

bryozoan-rich beds, until now, have not been reported (Taylor \& Allison 1998); the present work fills an important time gap in the bryozoan carbonate database.

Trepostomes described from the Smithian/Spathian of Nevada (Schäfer et al. 2003) bear taxonomic similarities to faunas from Ellesmere Island and Spitsbergen (Nakrem
\& Mørk 1991), and it seems reasonable to suggest a seaway connecting these palaeobasins. The bryozoans in the lowermost Triassic beds in central East Greenland mentioned by Trümpy (1960) are most probably reworked from underlying Permian strata, according to Teichert \& Kummel (1976). The correlation of Lower 
Triassic units of Ellesmere Island, central East Greenland and Spitsbergen with bryozoan occurrences is outlined in Fig. 6. For the present study, an inquiry to trace Trümpy's material was sent to Zürich, but no relevant material could be found (Hugo Bucher, pers. comm. 2007).

Recent fieldwork in Jameson Land, central East Greenland (Paul Wignall, pers. comm. 2005), has, however, revealed a small number of bryozoans in the basal part of the Wordie Creek Formation of Early Griesbachian age (Metophiceras subdemissum Zone) (Wignall \& Twitchett 2002). These bryozoans (Tabulipora sp.; Fig. 7a-c) may be reworked from the underlying fossiliferous late Permian Foldvik Creek Group. Tabulipora is the most common bryozoan genus in the upper Permian rocks of East Greenland (Sørensen et al. 2007), and it is considered that the bryozoans in the basal Wordie Creek Formation are reworked from the upper Permian, and consequently that Tabulipora did not survive into the Triassic.

\section{Sedimentology and paleoenvironments of the Ellesmere Island bryozoan beds}

Bryozoans occur in two different sedimentological settings: as scattered or common colonies associated with bivalves in a silt-shale matrix, and as more common colonies in a silty bioclastic limestone, accompanied by bivalves, crinoids and brachiopods. The identity of the bryozoans seems to be identical in both settings, with the presence of a species of Arcticopora, probably Arcticopora christei Fritz, 1961, but a revision is in progress in which the systematic position of this and other similar genera in the Triassic will be reconsidered (Nakrem \& Ernst unpubl. ms.).

The bryozoan colonies from the top of the Confederation Point Member (late Dienerian) are partly abraded, and have, to varying degrees, been transported (Fig. 3). It is interesting to note that in this high sedimentation rate terrigenous environment the skeletal carbonate factory was able to produce about $10 \mathrm{~m}$ of packstones and marly and sandy limestones. By comparison, the bryozoans from the upper Smith Creek Member occur as mixed debris in bioclastic tempestites (Fig. 4).

From thin-section observations, mollusc (aragonitic) shell moulds have been infilled with large sparry calcite crystals (drusy calcite void fill). No primary structures have been preserved. The micrite envelope consists of a small rim on the margin of the shells. Endolithic algae are present, and calcitic brachiopods are better preserved.

\section{Ellesmere Island bryozoan descriptions}

Eight thin sections from the top of the Confereration Point Member (late Dienerian), and four collections plus
18 thin sections from the top of the Smith Creek Member (late Smithian), have been investigated.

The bryozoans are all ramose branching colonies, and are generally well preserved. The colonies are not preserved in their living position, and they are abraded to varying degrees as a result of transportation. Less abraded colonies have well-preserved acanthostyles protruding out into the enclosing sediment (Fig. 8f). Other colonies have obviously been reworked from a semi(?)consolidated sediment, and have been transported in lithic clasts. This is interpreted from the existence of two types of sediment: one type filling the outer parts of the zooecia, and another type in the enclosing sediment (Fig. 8e). Some colonies display crushed endozones (Fig. 8d). Such structures can be interpreted as the postmortem collapse of central thin-walled colony parts. Crushed endozones are more common in competent beds (silt to sand and bioclastic limestones), as opposed to soft muds, and the compaction may thus be a result of overburden pressure. In places, some colonies have trapped "disturbing" grains (a biological reaction similar to the enclosure of grains forming pearls in molluscs). Some trapped grains are perhaps crinoid fragments (Fig. 8a). Organisms interpreted as encrusting microconchid tubeworms or foraminiferans are also observed to have been trapped between bryozoan growth layers (Fig. 8b).

Autozooecia and metazooecia with varying numbers of diaphragms have also been observed, often more closely spaced near the colony surface (Fig. 9a, b). Many colonies show a high degree of self-overgrowth, perhaps as a result of colony disturbance and partial destruction (Fig. 8c). Apertures are indented by acanthostyles in the shallowest thin sections, and are rounded and more oval in deeper sections (Fig. 9c, d). Large acanthostyles extend from the endozone into the exozone, whereas smaller acanthostyles appear in the exozone.

The Triassic bryozoan faunas are distinctly different from the underlying Late Permian faunas (Figs. $7 \mathrm{~d}-\mathrm{h}$ ).

\section{Summary}

In the palaeoboreal sea (north-west Pangaea) the skeletal carbonate factory ended at the Guadalupian mass extinction, but reappeared temporarily in the late Dienerian as distinct bryozoan beds.

The lower bryozoan beds with a post-extinction bloom of the genus Arcticopora document a repopulation interval in the Early Triassic, as exposed in the upper Confederation Point Member (Dienerian), with a lowdiversity/high-dominance assemblage of one or perhaps two taxa. It may indicate a rapid post-Permian recovery, 

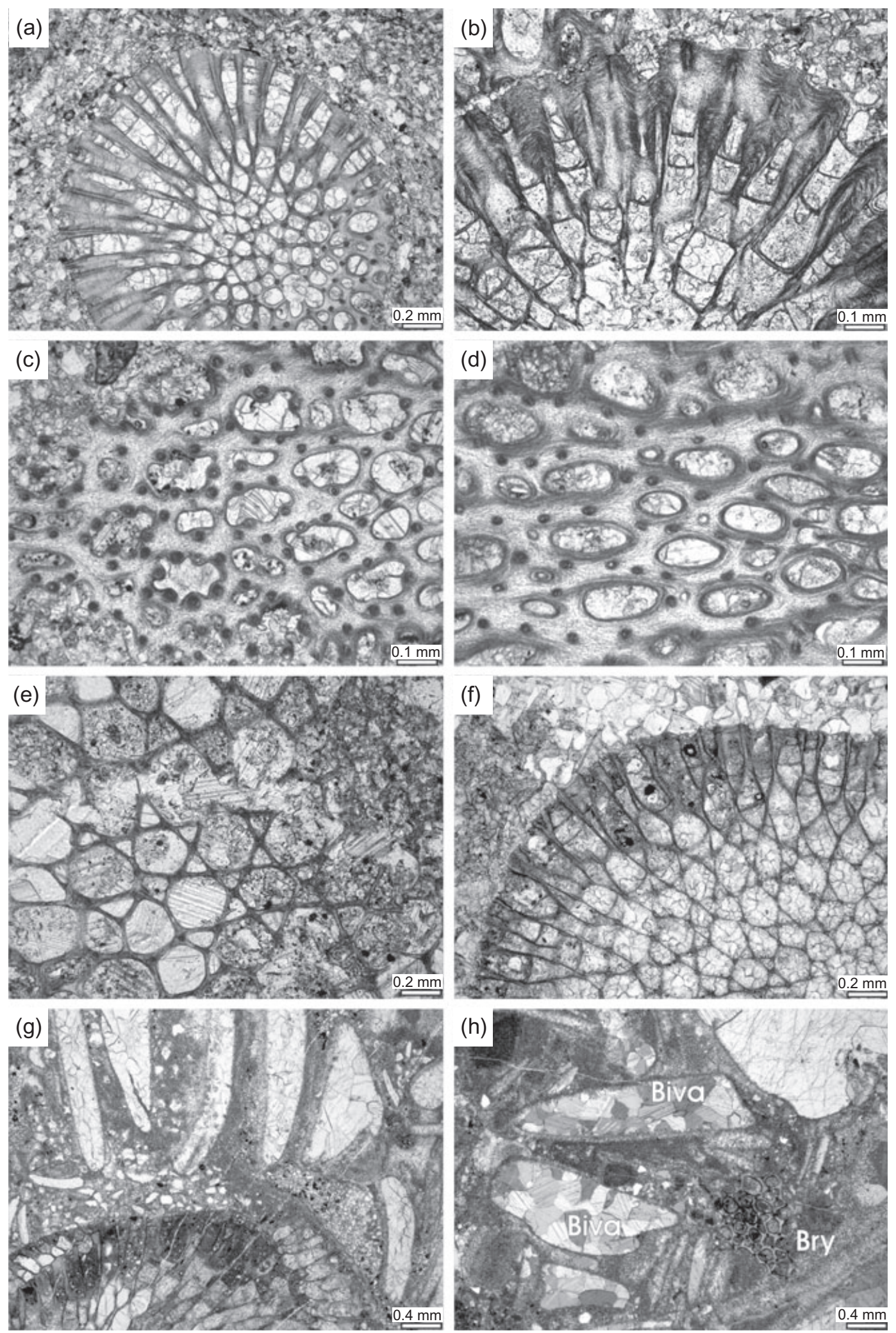
Fig. 9 (a) Arcticopora sp. transverse section; northern shore of Otto Fiord, $10 \mathrm{~m}$ below top of the Confederation Point Member, late Dienerian (palaeontological collection of the Natural History Museum, University of Oslo, PMO 170.791; collected by A. Baud \& B. Beauchamp). (b) Arcticopora sp. transverse section; Blue Mountains, Smith Creek Member, Smithian (PMO 138.111; collected by A. Embry). (c) Arcticopora sp. shallow tangential section, with oval zooecial apertures indented by acanthostyles; Blue Mountains, Smith Creek Member, Smithian (PMO 138.112; collected by A. Embry). (d) Arcticopora sp. tangential section, with oval zooecial apertures; Smith Creek Member, Smithian, Blue Mountains (PMO 138.112; collected by A. Embry). (e) Arcticopora sp. endozone displaying a star-shaped cross section caused by the packing of the zooecia, transverse section; northern shore of Otto Fiord, near top of the Confederation Point Member, late Dienerian (PMO 207.890; collected by A. Baud \& B. Beauchamp). (f) Arcticopora sp. with abraded surface, transverse section; south of the head of Otto Fiord, upper part of the Smith Creek Member, Smithian (PMO 170.787; collected by A. Baud \& B. Beauchamp). (g) Bryozoan (lower left) and recrystallized bivalves. South of the head of Otto Fiord, upper part of the Smith Creek Member, Smithian (PMO 170.788; collected by A. Baud \& B. Beauchamp). (h) Bryozoan (Bry) and recrystallized bivalves (Biva); south of the head of Otto Fiord, upper part of the Smith Creek Member, Smithian (PMO 170.788; collected by A. Baud \& B. Beauchamp).

and these bryozoans are interpreted as a pioneering, low-complexity palaeocommunity.

The upper bryozoan beds (Smithian), with a diverse benthic invertebrate fauna, are clearly referable to a more advanced recovery stage.

Axel Heiberg and Ellesmere islands are key places for studying the palaeoboreal latest Permian-early Triassic post-extinction radiation and recovery history.

\section{Acknowledgements}

AB thanks the University and the Geological Museum in Lausanne for assistance. Paul Wignall (Leeds) is thanked for providing East Greenland samples to HAN for study. Hugo Bucher (Zürich) is thanked for trying to locate Trümpy's Greenland material. HAN wishes to thank Andrej Ernst (Kiel) for valuable bryozoan discussion during the preparation of this paper. Eckart Håkansson (Copenhagen) and one anonymous reviewer suggested valuable improvements to the manuscript, and we greatly appreciate their help.

\section{References}

Astrova G.G. 1978. Istorija razvitija, sistema i filogenija mšanok: otrjad Trepostomata. (The history of development, system and phylogeny of the Bryozoa: order Trepostomata.) Trudy Paleontologičeskogo Instituta 169. Moscow: Paleontological Institute.

Baud A. \& Beauchamp B. 2006. Stratigraphic position of Lower Triassic bryozoan beds from Ellesmere Island, High Arctic, Canada. NGF Abstracts and Proceedings of the Geological Society of Norway 2006-3, 39-41.

Beatty T.W., Henderson C.M., Orchard M.J. \& Beauchamp B. 2006. Early Triassic (Induan) conodont biostratigraphy of the Sverdrup Basin, Canadian Arctic. NGF Abstracts and Proceedings of the Geological Society of Norway 2006-3, 41.

Beauchamp B. \& Baud A. 2002. Growth and demise of Permian biogenic chert along northwest Pangea: evidence for end-Permian collapse of thermohaline circulation. Palaeogeography, Palaeoclimatology, Palaeoecology $184,37-63$
Beauchamp B., Baud A. \& Henderson C.M. 1999. EndPermian demise of silica factories and implications for P-T extinction. Programme with abstracts of the XIV International Congress on the Carboniferous-Permian, August 17-21, Calgary, Canada. Pp. 8-9. Calgary: University of Calgary.

Bjerager M., Seidler L., Stemmerik L. \& Surlyk F. 2006. Ammonoid stratigraphy and sedimentary evolution across the Permian-Triassic boundary in East Greenland. Geological Magazine 143, 635-656.

Bolton T.E. 1961. Additional Arcticopora from the Triassic of northwestern Ellesmere Island. Proceedings of the Geological Association of Canada 13, 55-59.

Embry A.F. 1986. Stratigraphic subdivisions of the Blind Fiord and Bjorne formations (Lower Triassic), Sverdrup Basin, Arctic Islands. Current Research, Part B, Geological Survey of Canada, Paper 86-1B, 329-340.

Embry A.F. 1988. Triassic sea level changes: evidence from the Canadian Arctic Archipelago. In C.K. Wilgus et al. (eds.): Sea level changes: an integrated approach. Pp. 249-259. Tulsa, OK: Society of Economic Paleontologists and Mineralogists.

Embry A.F. 1991. Mesozoic history of the Arctic Islands. In H.P. Trettin (ed.): Geology of the Innuitian Orogen and Arctic Platform of Canada and Greenland. Geology of Canada. Vol. 3. Pp. 369-433. Ottawa: Geological Survey of Canada.

Embry A.F. 1997. Global sequence boundaries of the Triassic and their identification in the Western Canada Sedimentary Basin. Bulletin of Canadian Petroleum Geology $45,415-433$.

Ernst A. \& Nakrem H.A. 2005. Bryozoans from the Artinskian (Lower Permian) Great Bear Cape Formation, Ellesmere Island (Canadian Arctic). In H.I. Moyano et al. (eds.): Bryozoan studies 2004. Pp. 63-68. London: Taylor \& Francis.

Ernst A. \& Nakrem H.A. 2007. Lower Permian Bryozoa from Ellesmere Island (Canada). Paläontologische Zeitschrift 81, 17-28.

Fritz M.A. 1961. A new bryozoan genus from Lake Hazen, northeastern Ellesmere Island. Proceedings of the Geological Association of Canada 13, 52-55.

Gates L.M., James N.P. \& Beauchamp B. 2004. A glass ramp: shallow-water Permian spiculitic chert sedimentation, Sverdrup Basin, Arctic Canada. Sedimentary Geology 168, 125-147.

Gilmour E.H. \& Morozova I.P. 1999. Biogeography of the Late Permian Bryozoans. Paleontological Journal 33, 36-51. 
Henderson C.M. \& Baud A. 1997. Correlation of the Permian-Triassic boundary in Arctic Canada and comparison with Meishan, China. In W. Naiwen \& J. Remane (eds.): Stratigraphy. Proceedings of the 30 th International Geological Congress. Vol. 11. Pp. 143-152. Utrecht: VSP International Science Publishers.

Moore P.R. 1981. Mesozoic stratigraphy in the Blue Mountains and Krieger Mountains, northern Ellesmere Island, Arctic Canada; a preliminary account. Geological Survey of Canada, Current Research 81, 95-101.

Mørk A., Dallmann W.K, Dypvik H., Johannessen E.P., Larssen G.B., Nagy J., Nøttvedt A., Olaussen S., Pčelina T.M. \& Worsley D. 1999. Mesozoic lithostratigraphy. In W.K. Dallmann (ed.): Lithostratigraphic lexicon of Svalbard. Upper Palaeozoic to Quaternary bedrock. Review and recommendations for nomenclature use. Pp. 127-214. Tromsø: Nowegian Polar Institute.

Morozova I.P. 1986. Parastratigrafičeskie gruppy flory i fauny triasa. Ostatki morskih organizmov. Triasovye mšanki. (Parastratigraphic groups of flora and fauna of the Triassic. Marine organic remains. Triassic Bryozoa.) Trudy Vsesojuznogo Naučno-Issledovatel'skogo Geologičeskogo Instituta, New Series 334, 67-78. St. Petersburg: A.P. Karpinsky Russian Geological Research Institute.

Morozova I.P. \& Kručinina O.N. 1986. Permskie mšanki Arktiki (Zapadnyj Sektor). (The Permian bryozoans of the Arctic region [Western Sector].) Moscow: Akademija Nauk SSSR.

Nakrem H.A. \& Mørk A. 1991. New Early Triassic Bryozoa (Trepostomata) from Spitsbergen, with some remarks on the stratigraphy of the investigated horizons. Geological Magazine 128, 129-140.

Nelson C.S. 1988. An introductory perspective on nontropical shelf carbonates. Sedimentary Geology 60, 3-12.

Ogg J.G. \& Steiner M.B. 1991. Early Triassic magnetic polarity time scale integration of magnetostratigraphy, ammonite zonation and sequence stratigraphy from stratotype sections (Canadian Arctic Archipelago). Earth and Planetary Science Letters 107, 69-89.

Perch-Nielsen K., Birkenmajer K., Birkelund T. \& Aellen M. 1974. Revision of Triassic stratigraphy of the Scoresby Land and Jameson Land region, East Greenland. Meddelelser om Gronland 193. Copenhagen: Danish Polar Center.

Reid C.M., James N.P., Beauchamp B. \& Kyser T.K. 2007. Faunal turnover and changing oceanography: Late
Palaeozoic warm-to-cool water carbonates, Sverdrup Basin, Canadian Arctic Archipelago. Palaeogeography, Palaeoclimatology, Palaeoecology 249, 128-159.

Ross J.P.R. 1995. Permian Bryozoa. In P.A. Scholle et al. (eds.): The Permian of northern Pangea. Vol. 1. Paleogeography, paleoclimates, stratigraphy. Pp. 196-209. Berlin: Springer.

Ross J.P.R. \& Ross C.A. 1990. Late Palaeozoic bryozoan biogeography. Geological Society London Memoirs 12, 353-362.

Sakagami S. 1998. Permian bryozoans from North Ellesmere Island, Canadian Arctic Archipelago. Bulletin of the National Science Museum Tokyo C24, 67-91.

Schäfer P., Cuffey R.J. \& Young A.R. 2003. New trepostome Bryozoa from the Early Triassic (Smithian/Spathian) of Nevada. Paläontologische Zeitschrift 77, 323-340.

Schäfer P. \& Grant-Mackie J. 1994. Triassic Bryozoa from the Murihiku and Torlesse Supergroups, New Zealand. AAP Memoir 16. Canberra: Association of Australasian Palaeontologists.

Sørensen A.M., Håkansson E. \& Stemmerik L. 2007. Faunal migration into the Late Permian Zechstein Basin-evidence from bryozoan palaeobiogeography. Palaeogeography, Palaeoclimatology, Palaeoecology 251, 198-209.

Taylor P.D. \& Allison P.A. 1998. Bryozoan carbonates in space and time. Geology 26, 459-462.

Teichert C. \& Kummel B. 1976. Permian-Triassic boundary in the Kap Stosch area, East Greenland. Meddelelser om Grønland 197. Copenhagen: Danish Polar Center.

Thorsteinsson R. 1974. Carboniferous and Permian stratigraphy of Axel Heiberg Island and western Ellesmere Island, Canadian Arctic Archipelago. Geological Survey of Canada Bulletin 224.

Trümpy R. 1960. Über de Perm-Trias-Grenze in Ostgrønland und über die Problematik stratigraphischer Grenzen. (The Permian-Triassic boundary in East Greenland and the problem of stratigraphic boundaries.) Geologische Rundschau 49, 97-111.

Wignall P.B., Morante R. \& Newton R. 1998. The Permo-Triassic transition in Spitsbergen: $\delta^{13} \mathrm{C}_{\text {org }}$ chemostratigraphy, Fe and $\mathrm{S}$ geochemistry, facies, fauna and trace fossils. Geological Magazine 135, 47-62.

Wignall P.B. \& Twitchett R.J. 2002. Permian-Triassic sedimentology of Jameson Land, East Greenland: incised submarine channels in an anoxic basin. Journal of the Geological Society London 159, 691-703. 